\title{
'Hass' Avocado Carbohydrate Fluctuations. I. Growth and Phenology
}

\author{
Xuan Liu, Paul W. Robinson, Monica A. Madore, Guy W. Witney, ${ }^{1}$ and Mary Lu Arpaia ${ }^{2}$ \\ Department of Botany and Plant Sciences, University of California, Riverside, CA 92521
}

\begin{abstract}
AdDitional Index words. 'Hass' avocado, 'Duke 7' rootstock, D-mannoheptulose, Persea americana, perseitol, soluble sugar, starch

Abstract. Seasonal fluctuations in nonstructural carbohydrates (starch and soluble sugars) were studied in 'Hass' avocado (Persea americana Mill.) trees on 'Duke 7' rootstock over a 2-year period in southern California. On a dry weight basis, total soluble sugar (TSS) concentrations ranged from 33.0 to $236.0 \mathrm{mg}^{-1} \mathrm{~g}^{-1} \mathrm{dry}$ weight and were high compared to starch concentration ( 2.0 to $109.0 \mathrm{mg} \cdot \mathrm{g}^{-1}$ dry weight) in all measured organs (stems, leaves, trunks and roots). The seven carbon (C7) sugars, D-mannoheptulose and perseitol, were the dominant soluble sugars detected. The highest starch and TSS concentrations were found in stem tissues, and in stems, a distinct seasonal fluctuation in starch and TSS concentrations was observed. This coincided with vegetative growth flushes over both sampling years. Stem TSS and starch concentrations increased beginning in autumn, with cessation of shoot growth, until midwinter, possibly due to storage of photosynthate produced during the winter photosynthetic period. TSS peaked in midwinter, while starch increased throughout the winter to a maximum level in early spring. A second peak in stem TSS was observed in midsummer following flowering and spring shoot growth. At this time, stem starch concentration also decreased to the lowest level of the year. This complementary cycling between stem TSS and starch suggests that a conversion of starch to sugars occurs to support vegetative growth and flowering, while sugars produced photosynthetically may be allocated directly to support flowering and fruit production.
\end{abstract}

Avocado (Persea americana) is grown commercially primarily in three climatic zones: cool, semiarid climates with winter rainfall (characteristic of California); humid, subtropical areas with summer rainfall (e.g., South Africa) and tropical or semitropical zones with summer rainfall (e.g., Florida) (Whiley and Schaffer, 1994). Whole tree growth vigor and fruit production depends on the timing and extent of phenological events, which are under the control of tree carbon and energy availability and partitioning (Cannell, 1985; Daie, 1985; Priestley, 1987; Wolstenholme and Whiley, 1989) in response to environmental conditions (Davenport, 1982; Kaiser and Wolstenholme, 1994; Scholefield et al., 1985).

Starch and soluble sugars are the predominant reserve carbohydrates available for energy for growth and maintenance (Daie, 1985; Dey and Dixon, 1985). In tree crops such as avocado, the pattern of deposition of carbohydrate reserves in various storage organs is determined by carbohydrate use and mobilization processes occurring during the growing season. Thus, demands from competing sinks, represented by growing tissues such as fruits or shoots which will result not only in prevention of reserve formation from recently fixed carbon, but can also result in depletion of previously stored reserves (Liverira and Priestley, 1989; Wolstenholme, 1986). An understanding of how carbon is allocated to and from storage reserves throughout the growth cycle is essential to our understanding of mechanisms which control phenological processes such as shoot flush or fruit production (Cannell, 1985; Daie, 1985; Priestley, 1987; Wolstenholme and Whiley, 1989). Knowledge of the processes regulating carbohydrate supply and demand at different phenological stages would also allow development of management practices which would optimize growth and productivity

Received for publication 13 Nov. 1998. Accepted for publication 10 Aug. 1999 This project was funded, in part, by a grant-in-aid from the California Avocado Commission. The cost of publishing this paper was defrayed in part by the payment of page charges. Under postal regulations, this paper therefore must be hereby marked advertisement solely to indicate this fact.

${ }^{1}$ Current address: Abbott Laboratories, 508 Miller Street, Wenatchee, WA 98801.

${ }^{2}$ To whom reprint requests should be addressed.
(Wolstenholme and Whiley, 1989).

Previous studies on fruit tree crops have shown that carbohydrate reserves are related to fruit bearing and yield (Monselise and Goldschmidt, 1982). For example, in citrus (Citrus reticulata Blanco), high fruit bearing was associated with reduced starch reserves (Goldschmidt and Golomb, 1982). In avocado, a low concentration of starch reserves was shown to follow heavy production and conversely, a year of low production was followed by a high concentration of starch reserves in the trunk (Scholefield et al., 1985). Low starch reserves were also correlated with lower flowering intensity, fruit set, and yield (Van der Walt et al., 1993). However, other studies (Kaiser and Wolstenholme, 1994) have indicated that high concentrations of carbohydrate reserves do not necessarily result in more flowering, fruit set, and higher yield, as reserve carbohydrates can be used preferentially for vegetative growth (Kaiser and Wolstenholme, 1994). Others (Cannell, 1985; Finazzo et al., 1994; Priestley, 1987; Wibbe and Blanke, 1995) have also postulated that current canopy photosynthesis and/or the fruit bearing load may control final fruit production. Therefore, the purpose of this study was to analyze seasonal patterns of starch and soluble sugar concentrations of 'Hass' avocado, to determine the relationship between stored carbohydrate reserves and known phenological events, including fruit yield.

\section{Materials and Methods}

Plant Material. The experimental site was at the University of California, South Coast Research and Extension Center, Irvine, Calif. The trees used in this study were 'Hass' on 'Duke 7' rootstock, which were planted in 1986 at a $6.1 \times 6.1 \mathrm{~m}$ spacing (269 trees/ha). The soil type was Yolo fine sandy loam with an average depth $>18 \mathrm{~m}$. One drip emitter $\left(15.1 \mathrm{~L} \cdot \mathrm{h}^{-1}\right)$ was placed at the base of each tree. Two years after planting, the drip emitter was replaced with a single low volume minisprinkler $\left(45.5 \mathrm{~L} \cdot \mathrm{h}^{-1}\right)$ placed at the base of each tree. Trees were irrigated as needed using the reference evapotranspiration from the California Irrigation Management Information System (CIMIS) as a guideline (Snyder et 
al., 1985). Standard fertilization practices for California were maintained (Goodall et al., 1981). Samples for leaf mineral nutrient analysis were collected annually and fertilization adjusted so that leaf nutrient levels remained within the recommended guidelines (Goodall et al., 1981). Yield and tree size were recorded annually. Tree size was estimated by an empirical formula: $0.131 \mathrm{H}(\mathrm{W} 1+\mathrm{W} 2)^{2}$, where $\mathrm{H}$ is tree height and $\mathrm{W} 1$ and W2 are two perpendicular tree crown widths. Timing of flowering was also monitored during the bloom period in the study years. Shoot growth was monitored biweekly through the year by measuring shoot vertical extension of twenty branches of the northeast quadrant of each of the five selected trees.

Carbohydrate sampling. From May 1994 to June 1996, carbohydrate concentrations were determined in five trees chosen randomly from the experimental plot. Timing of flowering and vegetative shoot growth were also noted. Four plant organs were sampled: shoots, leaves, trunk (above the bud union) and roots. Samples were collected monthly between 1300 and 1500 HR mostly in the first or the fourth week of the month. Five shoot samples (7 cm in length) were selected from the southwest quadrant of each tree. The third mature leaf from the apex was collected from each shoot and its midsection $\left(\approx 30 \mathrm{~cm}^{2}\right)$ was used for analysis. All buds and other leaves were removed from the collected shoots and the remaining tissue was used for the stem sample. Trunk samples (three cores per tree, $0.5 \times 3.0 \mathrm{~cm}$ without bark) were taken on the south side of the tree $10 \mathrm{~cm}$ above the graft union using a Hagloff tree coring tool (Ben Meadows, Atlanta, Ga.). Root samples were taken at a distance of 1.5 to $2.0 \mathrm{~m}$ from the trunk within the wetted zone of the irrigation system. Roots in good condition (based on color and turgidity) were selected and sorted into fine and coarse roots (diameter $<2 \mathrm{~mm}$ and 2 to $5 \mathrm{~mm}$ ), respectively. The samples were transported on dry ice in an insulated container to the University of California, Riverside campus ( $65 \mathrm{~km}$ distance) and frozen at $-20^{\circ} \mathrm{C}$ overnight. Samples were then freeze-dried at -50 to $-51^{\circ} \mathrm{C}$ for $50 \mathrm{~h}$ in a Freeze Dry System/Freezone 4.5 (Labconco, Kansas City, Mo.) freeze-dryer, then ground using a Wiley mill to pass through a 40-mesh (0.635$\mathrm{mm})$ screen.

Chemicals. D-mannoheptulose and perseitol were obtained from Pfanstiel (Waukegon, Ill.). All other chemicals were purchased from Sigma Biochemicals (St. Louis, Mo.).

Sugar assay. Ground dried tissue $(0.1 \mathrm{~g})$ was added to $4 \mathrm{~mL} 80 \%$ ethanol and incubated in $80^{\circ} \mathrm{C}$ water bath for $30 \mathrm{~min}$ to extract the soluble sugars. The extract was centrifuged for $5 \mathrm{~min}$ at $4200 \mathrm{~g}_{\mathrm{n}}$ using a 5403 Centrifuge (Eppendorf, Hamburg, Germany) to pellet the tissue, the ethanol was decanted, and the tissues were reextracted three more times as above. A $6 \mathrm{~mL}$ portion of the pooled ethanol extract was then taken to dryness in a Speed Vac Concentrator (SAVANT, Farmingdale, N.Y.). The dried samples were resuspended in $1 \mathrm{~mL}$ deionized water and deionized using $1 \mathrm{~mL}$ anion and cation resin columns (AG1-X8/formate and AG50W-X8/ $\mathrm{H}^{+}, \mathrm{BIO}-$ RAD, Hercules, Calif.). Sugars were eluted with $15 \mathrm{~mL}$ water and $5 \mathrm{~mL}$ was taken to dryness as above. The sugars were then redissolved in 300 to $400 \mu \mathrm{L}$ water, filtered $(0.45 \mu \mathrm{m}$ pore size $)$ and then $20 \mathrm{~mL}$ was analyzed by HPLC using a Sugar-pak (Waters, Milford, Mass.) column. The separated sugars were detected using a 156 Refractive Index Detector (Altex, Fullerton, Calif.) with a 4290 data integrator (Varian, Sugarland, Texas) and quantified by comparison to known sugar standards.

STARCH ASSAY. The assay was based on procedures described by Madore (1990) and Hendrix (1993). The extracted residues were oven dried at $55^{\circ} \mathrm{C}$ and suspended in $2.0 \mathrm{~mL} 2 \mathrm{~N} \mathrm{KOH}$ and incubated in a boiling water bath for $1 \mathrm{~h}$ to gelatinize the starch. After cooling, $2.0 \mathrm{~mL} 2 \mathrm{~N}$ acetic acid was added to the samples to adjust the $\mathrm{pH}$ to 4.5 . The starch was then hydrolyzed to glucose using amyloglucosidase (Fluka, Ronkonkoma, N.Y.) (146 units for each sample in a total volume of $7 \mathrm{~mL}$ ). The glucose content was assayed using a commercially available kit (Sigma HK20) and quantified by comparison to a known glucose standard using a 3550-UV Microplate Reader (BIO-RAD) at $340 \mathrm{~nm}$. The final sugar and starch concentrations are reported as milligrams sugar or starch per gram of dry weight.

STATISTICAL ANALYSIS. Seasonal variation by month in sample sugar and starch concentrations was analyzed by month and year as well as differences between years using student's $t$ test (LSD method) by GLM procedures in SAS statistical package (SAS Inst., Inc., 1987). Differences between months and peak concentrations of sugar and starch by year are reported at $P \leq 0.05$.

\section{Results}

Plant growth Pattern. In southern California, the avocado tree may commence flowering in early March (Fig. 1). The flowering season can be protracted and may extend into May. The main fruit set period is usually between mid-April and May. Shoot growth measured as leaf budbreak and shoot elongation occurred in the spring between late March and early June (Fig. 1). Summer shoot growth commenced around mid-June and extended into autumn in late October (Fig. 1). Average fruit yield for 1994,1995 , and 1996 was $43.7 \pm 36.1,82.3 \pm 43.6$, and 53.6 \pm 16.2 $\mathrm{kg}$ per tree, respectively.

TOTAL SOLUBLE SUGARS (TSS) AND STARCH. High concentrations of soluble sugars were found in different organs of the trees (Fig. 1). The stems, leaves and roots had higher concentrations of TSS than starch (TSS: 33.0 to $236.0 \mathrm{mg} \cdot \mathrm{g}^{-1}$ dry weight, starch: 3.0 to $109.0 \mathrm{mg} \cdot \mathrm{g}^{-1}$ dry weight through both sampling seasons) (Fig. $1 \mathrm{~A}, \mathrm{~B}, \mathrm{D}$, and E). Only in the trunk tissue, were similar concentrations of starch and TSS detected (Fig. 1C). Stems had the highest concentrations of soluble sugars and starch (236.0 and $109.0 \mathrm{mg} \cdot \mathrm{g}^{-1}$ dry weight, respectively) compared to the leaves, trunk and roots (Fig. 1).

TSS concentration in the stem tissue fluctuated throughout $(P$ $\leq 0.05$ ) the year, corresponding to periods of shoot elongation, flowering, and early fruit growth (Fig. 1A). The cycling pattern differed between TSS and starch. Typically, two peaks of TSS were observed in a growth year and the timing of the TSS peaks were similar in both sampling years. TSS concentration increased significantly $(P \leq 0.05)$ from its lowest point in early spring to a maximum value in early summer corresponding to the maturation of the spring vegetative flush (late May and early June; $180.0 \pm$ $12.7 \mathrm{mg} \cdot \mathrm{g}^{-1}$ dry weight, $180.0 \pm 15.1 \mathrm{mg} \cdot \mathrm{g}^{-1}$ dry weight and 236.0 $\pm 23.6 \mathrm{mg} \cdot \mathrm{g}^{-1}$ dry weight in 1994,1995 , and 1996 , respectively, $P \leq 0.05$. TSS concentration then decreased significantly $(P \leq$ $0.05)$ to its lowest seasonal point $\left(116.0 \pm 9.9 \mathrm{mg} \cdot \mathrm{g}^{-1}\right.$ dry weight and $110.0 \pm 7.7 \mathrm{mg} \cdot \mathrm{g}^{-1}$ dry weight in 1994 and 1995 , respectively) as shoot growth resumed in the summer and extended into autumn. This was also the period of rapid fruit growth. The concentrations increased again $(P \leq 0.05)$ with the beginning of winter and peaked again in midwinter (early January; $181.0 \pm$ $13.6 \mathrm{mg} \cdot \mathrm{g}^{-1}$ dry weight in 1995 and $144.0 \pm 8.8 \mathrm{mg} \cdot \mathrm{g}^{-1}$ dry weight in 1996, years differ significantly from each other, $P \leq 0.05)$. From midwinter, TSS concentration decreased significantly $(P$ $\leq 0.05)$ to the annual minimum $\left(131.0 \pm 7.7 \mathrm{mg} \cdot \mathrm{g}^{-1}\right.$ dry weight in 1995 and $111.0 \pm 8.8 \mathrm{mg} \cdot \mathrm{g}^{-1}$ dry weight in 1996) in early spring. 
Only one peak of stem starch concentration was observed in each growth year. This peak occurred in February to March just before flowering, fruit set, and shoot growth (Fig. 1A). Very low concentrations of starch were measured throughout the summer and autumn (May to October) in both sampling years. Starch began to accumulate in stem tissue in December and rose significantly until March $\left(P \leq 0.05,109.2 \pm 15.9 \mathrm{mg} \cdot \mathrm{g}^{-1}\right.$ dry weight and $82.3 \pm 9.5 \mathrm{mg} \cdot \mathrm{g}^{-1}$ dry weight in 1994 and 1995 , respectively).

No significant seasonal fluctuation in leaf, trunk or root TSS or starch concentrations were observed (Fig. 1B-E). Seasonal leaf TSS concentrations were lower and ranged between 5.0 to $62.0 \mathrm{mg} \cdot \mathrm{g}^{-1}$ dry weight (Fig. 1B). Peak leaf starch and TSS concentrations were only observed in early summer which corresponded to completion of leaf expansion and maturation. TSS and starch concentrations in the trunk were similar to each other and ranged between 40.0 to $80.0 \mathrm{mg} \cdot \mathrm{g}^{-1}$ dry weight and 25.0 to $70.0 \mathrm{mg} \cdot \mathrm{g}^{-1}$ dry weight, respectively, over the sampling period (Fig. 1C). The coarse roots ( 2 to $5 \mathrm{~mm}$ diameter) had higher TSS and starch concentrations than the fine roots (Fig. $1 \mathrm{D}$ and E). The coarse root starch and TSS concentrations fluctuated irregularly and ranged between 6.9 to $76.0 \mathrm{mg} \cdot \mathrm{g}^{-1}$ dry weight and 46.0 to $112.0 \mathrm{mg} \cdot \mathrm{g}^{-1}$ dry weight, respectively, in the two measurement years (Fig. 1D). The fine roots ( $<2 \mathrm{~mm}$ diameter $)$ had a range of TSS concentrations between 33.0 to $72.0 \mathrm{mg} \cdot \mathrm{g}^{-1}$ dry weight and low starch concentrations (<17.0 $\mathrm{mg} \cdot \mathrm{g}^{-1}$ dry weight, Fig. 1E).

SEVEN-CARbon (C7) SUGARS. D-mannoheptulose and perseitol were the predominant soluble sugars found in all measured tissues (Fig. 2). D-mannoheptulose concentrations ranged between 36.0 to $99.0 \mathrm{mg} \cdot \mathrm{g}^{-1}$ dry weight in the stem, 8.0 to $87.0 \mathrm{mg} \cdot \mathrm{g}^{-1}$ dry weight in leaves, 6.0 to $26.0 \mathrm{mg} \cdot \mathrm{g}^{-1}$ dry weight in the trunk, 10.0 to $72.0 \mathrm{mg} \cdot \mathrm{g}^{-1}$ dry weight in the fine roots, and 11.0 to $42.0 \mathrm{mg} \cdot \mathrm{g}^{-1}$ dry weight in the coarse roots. Perseitol concentrations ranged between 35.0 to $76.0 \mathrm{mg} \cdot \mathrm{g}^{-1}$ dry weight in the stem, 18.0 to $44.0 \mathrm{mg} \cdot \mathrm{g}^{-1}$ dry weight in the leaves, 23.0 to $41.0 \mathrm{mg} \cdot \mathrm{g}^{-1}$ dry weight in the trunk, 16.0 to $34.0 \mathrm{mg} \cdot \mathrm{g}^{-1}$ dry weight in the fine roots, and 23.0 to $59.0 \mathrm{mg} \cdot \mathrm{g}^{-1}$ dry weight in the coarse roots. These two C7 sugars together accounted for the majority of the TSS in the stems $(67 \%$ to $90 \%)$, leaves $(39 \%$ to $71 \%)$, trunk $(61 \%$ to $81 \%)$, fine roots $(67 \%$ to $87 \%)$ and coarse roots $(73 \%$ to $88 \%$ ) of the TSS in the stems, leaves, trunk, fine roots and coarse roots. The seasonal patterns of stem TSS concentrations are reflected in the seasonal fluctuation of these C7 sugars (Fig. 2).

\section{Discussion}

This study demonstrates clearly that soluble seven carbon (C7) sugars, are the major form of carbohydrate reserve in 'Hass' avocado. Previous avocado research (Scholefield et al., 1985), which focused only on starch reserves, overlooked the importance of the C7 sugars in carbon allocation processes in this tree crop. Other fruit trees, such as apple [Malus sylvestris Mill. var. domestica (Borkh.) Mansf], peach [Prunus persica (L.) Batsch (Peach Group)] (Loescher and Everard, 1996; Sakai, 1966), and olive (Olea europaea L.) (Flora and Madore, 1993) produce six carbon sugar alchohols such as sorbitol and mannitol as major photosynthetic products. Avocado also pro-

Fig. 1. Seasonal fluctuations of starch and total soluble sugar concentrations in the (A) stems, (B) leaves, (C) trunk, (D) coarse roots, and (E) fine roots of 'Hass' avocado on 'Duke 7' rootstock from May 1994 to June 1996. Vertical bars represent $\pm 1 \mathrm{SE}, \mathrm{n}=5$ (trees). The timing of flowering and vegetative growth are indicated by the horizontal bars.

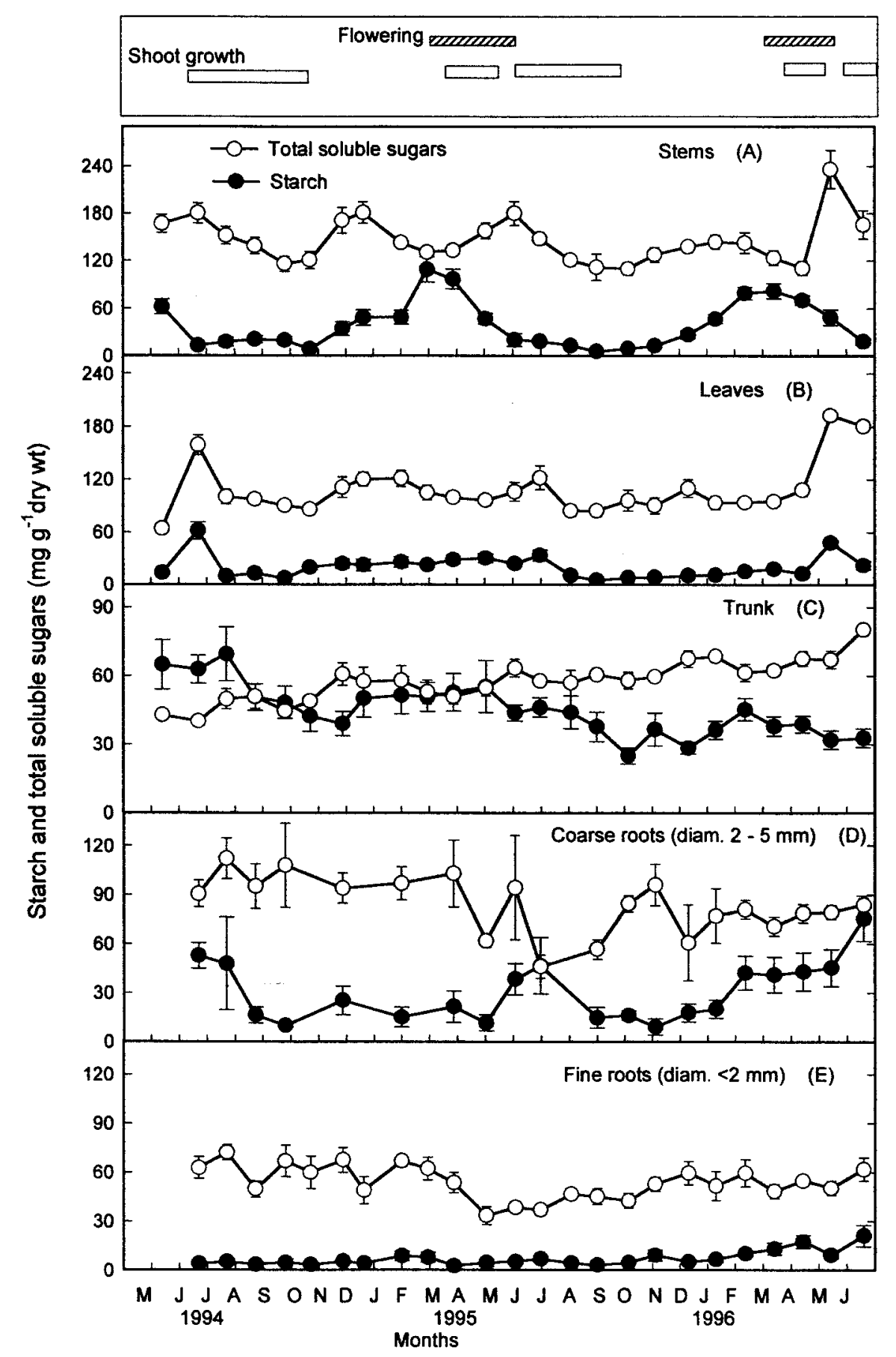




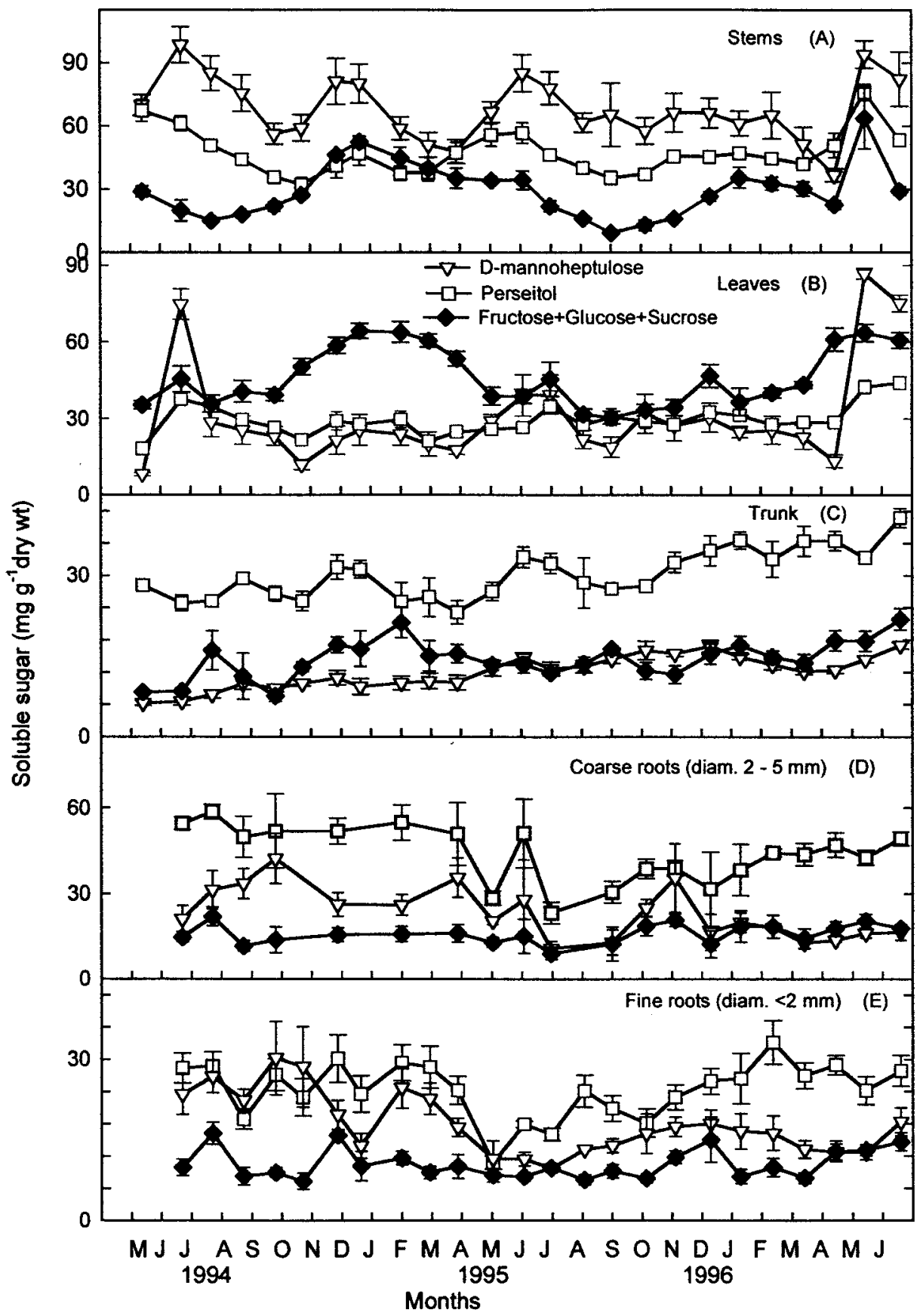

produced by winter photosynthesis, as indicated by the increase in TSS and starch concentrations in the stems during the winter (Fig. 1A). The winter sugar peak coincided with the coolest annual temperatures (at the experimental site, the mean daily minimum temperature from December to January was 7.2 and $7.5^{\circ} \mathrm{C}$ for Winters 1994-95 and 1995-96, respectively). This suggests that sugar accumulation might be acting to enhance shoot cold hardiness (Kramer and Kozlowski, 1979). Shoot inflorescence expansion was first noticeable in January although flower initiation occurs several months earlier in avocado (Salazar et al., 1998). Stem carbohydrate reserves might therefore be an important reserve for panicle development, which demands carbohydrate energy input (Jackson and Sweet, 1972). This might explain the decline in reserves observed following the winter peak. Additionally, the decrease in stem TSS from winter peak levels coincided with an increase in stem starch in spring, suggesting that soluble sugars may be converted to starch during this period of warming. Alternatively, springtime starch accumulation in the stem may result from leaf photosynthesis.

Active tree growth in the spring resulted in a decline in stored stem reserves (Fig. 1A), but did not appear to involve significant use of the carbohydrate reserves from the trunk and roots, since no corresponding fluctuation in carbohydrates was observed in these organs. Presumably, stem energy stores were used to support flowering, fruit set, and vegetative growth that occurred during this phase of the growth cycle. Similarly, the decline in stem TSS during the period of early summer to September reflected carbon use fuelling the summer vegeta-

Fig. 2. Seasonal fluctuations of soluble sugar concentrations in the (A) stems, (B) leaves, $(\mathbf{C})$ trunk, $(\mathbf{D})$ coarse roots, and (E) fine roots of 'Hass' avocado on 'Duke 7' rootstock from May 1994 to June 1996. Vertical bars represent \pm 1 sE, $\mathrm{n}=5$ (trees).

duces a sugar alcohol, the heptitol perseitol, which is the polyhydroxy derivative of the $\mathrm{C} 7$ reducing sugar, mannoheptulose. Both of these C7 sugars are major components of all plant organs investigated, as demonstrated in this study. Avocado is also a nondeciduous tree, and so its seasonal carbon allocation processes can be expected to differ from those determined for deciduous species. Avocado continues to photosynthesize throughout the winter season, and can therefore supplement its stored reserves with recently fixed carbon. Our data suggest that during the winter dormant period, the trees may store more carbon tive flush and the period of rapid fruit expansion. Carbohydrates assimilated through canopy photosynthesis of source leaves also contributed to the summer vegetative flush and fruit growth, as very little photoassimilated carbon was apparently partitioned towards storage during this period.

The relationship between fruit yield and carbohydrate storage is complex (Scholefield et al., 1985; Van der Walt et al., 1993). High fruit yield in avocado may not necessarily be associated with lower carbohydrate reserves in the tree, as leaf photosynthesis may be able to produce sufficient carbohydrate for strong carbon demands at critical growth periods (Finazzo et al., 1994; Kaiser and Wolstenholme, 1994; Thorp et al., 1993). Thus, avocado trees growing under optimal environmental conditions with good management may be able to maintain their energy levels during fruit production without having to overdraw on 
stored stem carbohydrate reserves (Monselise and Goldschmidt, 1982). In apple trees (Wibbe and Blanke, 1995), and also in avocado (Schaffer et al., 1987), photosynthesis has been shown to be higher in bearing trees than in nonbearing trees. Enhanced photosynthesis may allow production of more carbohydrates to support fruit growth and therefore reduce dependency on stored carbohydrate reserves. Additionally, plant hormones may play a decisive role in carbon allocation processes by controlling flowering, fruit set, and thus final fruit yield (Jackson and Sweet, 1972; Martens et al., 1994). For example, gibberellic acid, produced by the endocarp of avocado fruit in a heavy yield year, was observed to inhibit flowering and fruit set the following year (Martens et al., 1994; Van der Walt et al., 1993). Thus, carbohydrate reserve strength alone is unlikely to provide sufficient explanations for complex phenological processes, such as the alternate bearing problem in avocado.

The present study clearly indicates that oscillations in stored carbohydrate reserves are an important part of avocado phenology. Additionally, this study also shows that, in avocado, C7 sugars are the primary contributors to these reserves. These C7 sugars are rare sugars in nature and have been found only in a few plant species (Richtmyer, 1970). There is no clear explanation as to why avocado diverts such a large proportion of fixed carbon source to these unusual sugars. Further research is needed to focus on this aspect of avocado carbohydrate metabolism.

\section{Literature Cited}

Cannell, M.G.R. 1985. Dry matter partitioning in tree crops, p. 160-193. In: M.G.R. Cannell and J.E. Jackson (eds.). Attributes of trees as crop plants. Inst. Terrestrial Ecol., Huntington, U.K.

Daie, J. 1985. Carbohydrate partitioning and metabolism in crops. Hort. Rev. 7:69-108.

Davenport, T.L. 1982. Avocado growth and development. Proc. Fla. State Hort. Soc. 95:92-96.

Dey, P.M. and R.A. Dixon. 1985. Preface, p. xi. In: P.M. Dey and R.A. Dixon (eds.). Biochemistry of storage carbohydrates in green plants. Academic Press, Orlando, Fla.

Finazzo, S., T.L. Davenport, and B. Schaffer. 1994. Partitioning of photoassimilates in avocado (Persea americana Mill.) during flowering and fruit set. Tree Physiol. 14:153-164.

Flora, L.L. and M.A. Madore. 1993. Stachyose and mannitol transport in olive (Olea europaea L.). Planta 189:484-490.

Goldschmidt, E.E. and A. Golomb. 1982. The carbohydrate balance of alternate-bearing citrus trees and the significance of reserves for flowering and fruiting. J. Amer. Soc. Hort. Sci. 107:206-208.

Goodall, G.E., T.W. Embleton, and R.G. Platt. 1981. Avocado fertilization. Univ. of Calif. Div. Agr. Sci. (Oakland) Lflt. 2024.

Hendrix, D.L. 1993. Rapid extraction and analysis of nonstructural carbohydrates in plant tissues. Crop Sci. 33:1306-1311.

Jackson, D.I. and G.B. Sweet. 1972. Flower initiation in temperate woody plants. Hort. Abstr. 42:9-24.

Kaiser, C. and B.N. Wolstenholme. 1994. Aspects of delayed harvest of 'Hass' avocado (Persea americana Mill.) fruit in a cool subtropical climate. II. Fruit size, yield, phenology and whole-tree starch cycling. J. Hort. Sci. 69:447-457.
Kramer, P.J. and T.T. Kozlowski. 1979. Environmental and cultural factors affecting growth, p. 645-665. In:P.J. Kramer and T.T. Kozlowski (eds.). Physiology of woody plants. Academic Press, London.

Liverira, C.M. and C. Priestley. 1989. Carbohydrate reserves in deciduous fruit trees. Hort. Rev. 10:403-430.

Loescher, W.H. and J.D. Everard. 1996. Sugar alcohol metabolism in sinks and sources, p. 185-207. In: E. Zamski and A.A. Schaffer (eds.). Photoassimilate distribution in plants and crops, source-sink relationships. Marcel Dekker, New York.

Madore, M.A. 1990. Carbohydrate metabolism in photosynthetic and nonphotosynthetic tissues of variegated leaves of Coleus blume $i$ Benth. Plant Physiol. 93:617-622.

Martens, D.A., S. Luck, and W.T. Frankenberger, Jr. 1994. Role of plant growth regulators in vegetative spring flush, flowering and fruit drop in avocado (Persea americana Mill.). Spec. Rpt. Calif. Avocado Dev. Org., Calif. Avocado Soc., Saticoy.

Monselise, S.P. and E.E. Goldschmidt. 1982. Alternate bearing in fruit trees. Hort. Rev. 4:128-173.

Priestley, C.A. 1987. Source-sink relations of fruit trees, p. 81-97. In: M.R. Sethuraj and A.S. Raghavendra (eds.). Tree crop physiology. Elsevier, Amsterdam.

Richtmyer, N.K. 1970. The isolation of volemitol and other polyhydric alcohols from avocado seeds. Carbohydrate Res. 12:135-138.

Sakai, A. 1966. Seasonal variations in the amounts of polyhydric alcohol and sugar in fruit trees. J. Hort. Sci. 41:207-213.

Salazar, G.S., E.M. Lord, and C.J. Lovatt. 1998. Inflorescence and flower development of the 'Hass' avocado (Persea americana Mill.) during "on" and "off" crop years. J. Amer. Soc. Hort. Sci. 123:537544.

SAS Institute, Inc. 1987. Proprietary software release 6.04. SAS Inst., Cary, N.C.

Schaffer, B., L.R. Ramos, and S.P. Lara. 1987. Effect of fruit removal on net gas exchange of avocado leaves. HortScience 22:925-927.

Scholefield, P.B., M. Sedgley, and D.McE. Alexander. 1985. Carbohydrate cycling in relation to shoot growth, floral initiation and development and yield in the avocado. Scientia Hort. 25:99-110.

Snyder, R., D.W. Henderson, W.O. Pruitt, and A. Dong. 1985. California irrigation management information system: Final Rpt. Land, Air, and Water Resources Papers 10013 A, B, C. Dept. Land, Air, and Water Resources, Univ. of Calif. Davis.

Thorp, T.G., D. Aspinall, and M. Sedgley. 1993. Influence of shoot age on floral development and early fruit set in avocado (Persea americana Mill.) cv. Hass. J. Hort. Sci. 68:645-651.

Van der Walt, M., S.J. Davie, and D.G. Smith. 1993. Carbohydrate and other studies on alternate bearing Fuerte and Hass avocado trees. S. Afr. Avocado Growers' Assn. Yrbk. 16:82-85.

Wibbe, M.L. and M.M. Blanke. 1995. Effects of defruiting on sourcesink relationship, carbon budget, leaf carbohydrate content and water use efficiency of apple trees. Physiol. Plant. 94:529-533.

Whiley, A.W. and B. Schaffer. 1994. Avocado, p. 1-35. In: B. Schaffer and P.C. Andersen (eds.). Handbook of environmental physiology of fruit crops. vol. 2. Subtropical and tropical crops. CRC Press, Boca Raton, Fla.

Wolstenholme, B.N. 1986. Energy costs of fruiting as a yield-limiting factor with special reference to avocado. Acta Hort. 175:121-126.

Wolstenholme, B.N. and A.W. Whiley. 1989. Carbohydrate and phenological cycling as management tools for avocado orchards. S. Afr. Avocado. Growers' Assn. Yrbk. 12:33-37. 